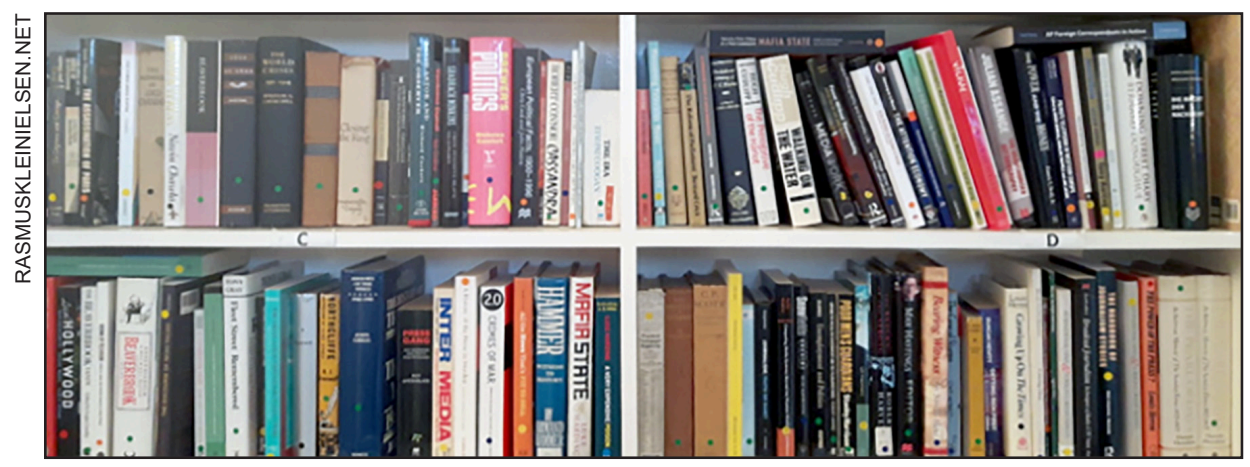

BOOKSHELF

\section{Guide to best practice journalism in the future}

IN THIS edition of Pacific Journalism Review we begin a new section, Bookshelf, where we ask our regular contributors to pick three books that have played an important part of their academic, professional and writing lives. We begin with this selection by retired journalism academic, blogger and regular contributor to these pages, LEE DUFFIELD.

SuperMedia: Saving Journalism so it can Save the World, by Charlie Beckett. Chichester, UK: Wiley-Blackwell. 2008. 216 pages. ISBN 9781405179249.

The Paradox of Power for Journalists: back to the future of news, by Charlie Beckett. London, UK: London School of Economics, 2018. https://bit.ly/2YnVz6x
BRITISH journalist Charlie Beckett published his influential book Supermedia on the response of news media to the advent of digitisation in 2008, then updated it a decade later.

He saw both the threats to journalism in the 'new economy', and opportunities contained in developments like citizen journalism; producing his own scheme for working journalists to collaborate with audience members. As a university professor in 2018, he published a revision, The Paradox of Power for Journalists, confirming the original thesis that: journalism, both 'threatened and empowered' by new forms like social media, had adjusted, and could have 'more impact than ever before'. Beckett's perceptive analysis of sweeping changes has become a guide to the continuation of best practice in journalism into the future.

At The Barricades, by Wilfred Burchett. London, UK: Macmillan, 1981. 341 pages. ISBN 0333337271

WILFRED Burchett's memoir At the Barricades is recommendable to aspiring journalists, showing how pursuit of news can be a consuming mo- 
tivator in professional and personal identity. This mentality led him to memorable stories, eclipsing the obloquy he suffered for left-wing sentiments.

In 1945, Burchett avoided covering the Japanese surrender in Tokyo, instead travelling alone to Hiroshima after hearing rumours of a deadly sickness, from radiation. His London Express headline 'Atomic Plague' scooped reports of the predictable surrender. As an Australian farm boy travelling in China he'd been shocked by cruelty and exploitation in the factories. He reported decades of the Cold War for Western media from the communist side. When he visited Australian prisoners of war in North Korea, the gesture was rejected, and his passport cancelled.

Paradise Lost, by John Milton. First published 1667. This edition edited by Alastair Fowler, London, UK: Routledge, 2013, 744 pages. ISBN 13:978140583278-6

WITH any journalism being ultimately about writing, John Milton's 1667 epic poem Paradise Lost is among the purest models available. Drawing on Genesis, classical mythology, other writers such as Dante, lessons from the English civil war; Milton's Adam and Eve story creates suspense even though its outcome is known in advance. The blind poet would dictate lucid passages mostly to his daughter. Readers can identify and gasp at whole sections which hold together almost as discrete works, yet which are integrated with the whole. One of

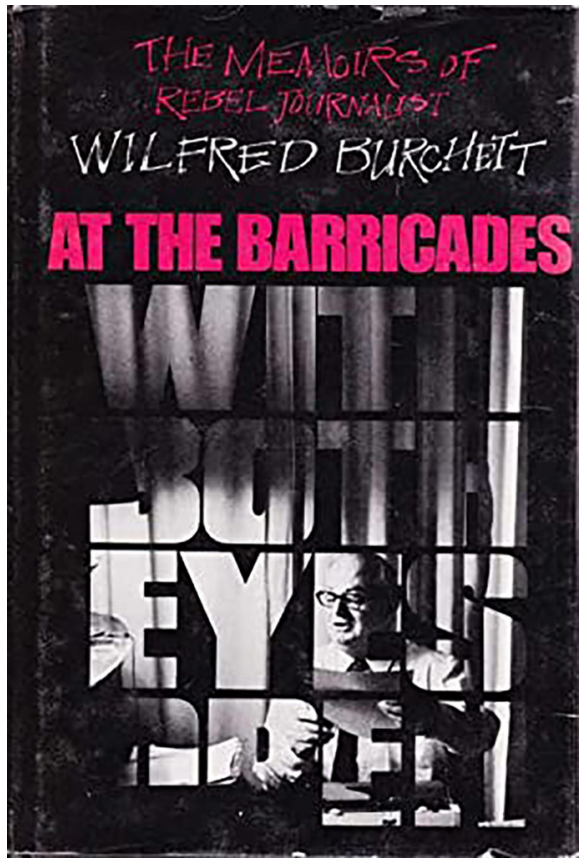

the richest celebrates the filling of the air and seas on the World's fifth day, with birds, and sealife, "that with their fins and shining scales glide under the green wave' (Book VII, 401-2).

The lessons of Milton's writing are clear: Have depth, knowledge; consider each word, each image; be steadfastly clear; accept that even if you can't ever be this good, trying is valuable. 